\title{
RELEVANSI PADA IKLAN PRODUK PERAWATAN BAYI: SEBUAH ANALISIS PRAGMATIK
}

\author{
Isnain Hidayanti, Neneng Nurjanah \\ isnain359@gmail.com,neneng.nurjanah@uinjkt.ac.id \\ UIN Syarif Hidayatullah Jakarta
}

Diserahkan: 18 Maret 2021, Direvisi: 29 April 2021, Diterima: 22 Juni 2021

\begin{abstract}
An advertisement is here to introduce its product to interlocutors (market share) by utilizing language and communication that involves contextual effects and an ostentive stimulus. That is also what is used in the ad for Johnson's product. To find out the form of communication in Johnson's baby product advertisements, Sperber and Wilson's theory of relevance will be used. The theory of advertising is also used in pragmatic studies according to Tanaka. The purpose of this study was to determine the relevance and meaning of the utterances in J\&J product advertisements, namely The New Johnson's ${ }^{\circledR}$ Cotton Touch 2 in 1 Hair \& Body Baby Bath. The results showed that the first, Johnson's CottonTouch 2 in 1 Hair \& Body Baby Bath ad has a high degree of relevance because it utilizes a lot of contextual effects and does not require a long process in processing the ad. Second, the meaning of speakers conveyed by advertising agencies is that this product is a soft product, in accordance with health and halal standards so that these baby products can be used by various levels of society.
\end{abstract} Keywords: Relevance Theory, the Meaning of Speech, Advertising, Pragmatic 


\begin{abstract}
Abstrak
Sebuah iklan hadir untuk memperkenalkan produknya kepada lawan tutur (pangsa pasar) dengan memanfaatkan bahasa dan komunikasi yang melibatkan efek kontekstual dan stimulus ostentif. Hal itu pulalah yang digunakan pada iklan produk Johnson's. Untuk mengetahui bentuk komunikasi dalam iklan produk bayi Johnson's, maka akan dipakai teori relevansi Sperber dan Wilson. Digunakan pula teori iklan dalam kajian pragmatik menurut Tanaka. Tujuan penelitian ini adalah untuk mengetahui relevansi dan makna tuturan dalam iklan produk J\&J, yaitu The New Johnson's ${ }^{\circledast}$ Cotton Touch 2in1 Hair\&Body Baby Bath. Hasil penelitian menunjukkan bahwa pertama, iklan Johnson's CottonTouch 2in1 Hair \& Body Baby Bath memiliki derajat relevansi yang tinggi karena memanfaatkan efek kontekstual yang banyak dan tidak membutuhkan proses yang lama dalam memproses iklan tersebut. Kedua, makna penutur disampaikan oleh agensi iklan adalah produk ini merupakan produk yang lembut, sesuai dengan standar kesehatan dan halal sehingga produk bayi tersebut dapat digunakan oleh beragam lapisan masyarakat.
\end{abstract}

Kata Kunci: Teori Relevansi, Makna Tuturan, Iklan, Pragmatik

\title{
Pendahuluan
}

Kajian pragmatik telah ada sejak lama. Pragmatik adalah kajian atau studi yang membahas antara bahasa dan pemakainya. Dengan demikian, harus dikatakan pula bahwa segala dimensi dan apapun komponen yang berkaitan dengan sosok pemakai bahasa harus dipertimbangkan dan diperhitungkan dengan teliti dan cermat. Manfaat dari studi pragmatik banyak sekali. Kunjana Rahardi berpendapat bahwa pragmatik bisa dimanfaatkan dalam standarisasi bahasa. Dengan standarisasi, bahasa dapat lebih mudah dipelajari siapapun baik penutur bahasa itu sendiri, maupun orang-orang di luar masyarakat bahasa tersebut. Selain dimanfaatkan untuk pembakuan bahasa, pragmatik juga dimanfaatkan dalam berbagai penelitian mengenai tuturan, perilaku, dan lainnya (Rahardi, 2019: 6). 
Iklan merupakan objek yang seringkali dikaji menggunakan ilmu pragmatik. Beberapa di antaranya dipadukan dengan psikologi yang kemudian menjadi penelitian psikopragmatik. Selain dikaji dari sisi pragmatik, iklan juga dikaji dari berbagai disiplin ilmu, seperti sastra, ekonomi, manajemen, dan lain-lain. Iklan merupakan salah satu bentuk komunikasi yang digunakan oleh produsen untuk menginformasikan kepada kawan tutur (pangsa pasar) tentang produk dan keunggulannnya. Melalui iklan, produsen berharap produk tersebut mendapatkan citra positif sehingga produknya laris di pasaran. Hal ini tentu agar produsen mendapatkan untung dari hasil penjualan karena biaya untuk pembuatan dan penyebaran iklan tidaklah murah.

Penelitian ini mengambil iklan produk bayi sebagai objek yang diteliti. Peneliti melihat masih belum banyak yang mengkaji iklan produk bayi dari sisi pragmatik, khususnya dengan menggunakan teori relevansi. Mayoritas kajiannya masih pada ruang lingkup nilai ekonomisnya. Menurut hemat peneliti, produk bayi merupakan salah satu pasar yang cukup menjanjikan di dunia persaingan bisnis, terlebih di Indonesia. Tercatat sebanyak 12.334 bayi telah lahir pada hari pertama tahun 2021. Indonesia menduduki peringkat kelima dalam proyeksi kelahiran berdasarkan prediksi Dana Anak-Anak Perserikatan Bangsa-Bangsa (UNICEF). Maka, menjadi hal yang wajar jika di Indonesia muncul berbagai iklan produk bayi seperti, Cussons, Johnson's, Pigeon, Zwitsal, Mitu, My Baby, dan lain-lain.

Setiap perusahaan bersaing supaya setiap poduk bayi yang mereka produksi menjadi pilihan para ibu. Melalui iklan, mereka memperkenalkan dan menyampaikan keunggulan dari masingmaisng produk bayinya. Oleh karena itu, iklan pada umumnya menggunakan bahasa yang baik, mudah dipahami, dan bersifat persuasif. Selain itu, iklan pun dibuat menarik secara visual supaya kawan tutur tertarik sehingga berpotensi membeli produk tersebut.

J\&J merupakan nama perusahan dari produk bayi Johnson's. Mereka telah banyak mengeluarkan produk untuk perlengkapan bayi, seperti sampo, bedak, baby oil, lotion, baby cologne, baby bath, 
sabun mandi, dan perawatan rambut. Produk perawatan untuk bayi yang dijual oleh J\&J sudah banyak dikenal oleh kalangan ibu. Selain manfaat dari produk tersebut, iklan yang dikeluarkan Johnson's tersebut mampu membuat orang tertarik. Tagline diterakan pada dari produk bayi J\&J adalah "wanginya bayi banget”.

Aspek pragmatis dalam tuturan iklan menjadi perhatian dalam penelitian ini. Menurut Tanaka (Nurjanah, 2016), tuturan yang ada dalam iklan memang tidak hanya sekadar memberikan informasi tertentu, melainkan untuk membujuk, meyakinkan, dan memanipulasi pemahaman pangsa pasarnya. Jika dilihat sekilas dari produk tersebut, iklan tersebut berusaha membangun pemahaman pangsa pasarnya mengenai kondisi kulit bayi dan kebutuhan atas perawatannya.

Dalam menganalisis tuturan yang disampaikan melalui iklan dapat dikaji dengan pendekatan pragmatis yaitu, dengan menggunakan teori relevansi milik Dan Sperber dan Deirdre Wilson. Melalui pendekatan pragmatis, diketahui bahwa antara penutur dan kawan tutur melakukan komunikasi. Komunikasi terjadi apabila kawan tutur (pangsa pasar) menonton atau membaca iklan. Bentuk komunikasinya adalah komunikasi tidak langsung atau samarsamar (covert communication) antara agensi iklan dengan pangsa pasarnya. Teori relevansi berpandangan bahwa dalam komunikasi tersebut kawan tutur berusaha menafsirkan tuturan iklan dengan pengetahuan atau sejumlah asumsi yang berada dalam bentuk pangsa pasanya (efek kontekstual) (Nurjanah, 2016: 69).

Teori relevansi akan membahas hubungan komunikasi yang dibentuk oleh agensi iklan dengan kawan tuturnya (pangsa pasar) melalui tuturan dan asumsi. Menurut Tanaka (Nurjanah, 2016), teori relevansi menyediakan catatan komprehensif mengenai penafsiran sebuah tuturan.

Berdasarkan latar belakang yang telah dipaparkan, artikel ini akan membahas relevansi iklan produk J\&J, yaitu The New Johnson's CottonTouch 2in1 hair and body baby bath. Kemudian didapatkan rumusan masalahnya adalah, (1) bagaimana relevansi produk iklan 
perawatan bayi? dan (2) bagaimana makna tuturan dalam iklan produk bayi tersebut?

\section{KAJIAN LITERATUR}

\section{Teori Relevansi}

Rahardi, dkk. (2019: 53-57) menyatakan bahwa dalam aktivitas berbahasa harus ada semacam kerja sama antara penurut dan mitra tutur. Bentuk kerja sama tersebut diejawantahkan melalui maksim kerja sama yaitu, maksim kuantitas, maksim kualitas, maksim relasi (relevansi), dan maksim cara. Namun, menurut Sperber dan Wilson semua maksim Grice dapat diringkas satu maksim saja, yaitu maksim relasi atau relevansi. Prinsip relevansi yang menyatakan bahwa penutur berusaha bersikap serelevan mungkin dalam berbagai keadaan yang bisa diuraikan secara benar, dapat mengatasi sejumlah besar data yang memang dirancang untuk dijelaskan oleh maksimmaksim Grice (Sperber dan Wilson, 1991: 381).

Prinsip relevansi ini memiliki tiga ciri menurut Sperber dan Wilson (dalam Cummings, 2007: 25). Pertama, daya terapan prinsip relevansi tidak hanya pada komunikasi, tetapi juga pada bidang kognisi. Melalui prinsip ini, Sperber dan Wilson ingin mengatakan bahwa saat seorang penutur berbicara dengan kawan tutur, sebetulnya aspek kognisi memiliki peran dalam komunikasi bahkan komunikasi dikatakan sebagai bagian dari aspek kognisi. Kedua, adalah perwujudan karakteristik ekonomisnya adalah konsekuensi langsung asal usul kognitif prinsip ini atau prinsip untung rugi. Dengan kata lain, dalam komunikasi seseorang dapat memperoleh untung dan rugi berdasarkan efek kontekstual atau pembaharuan skemata dalam benak seseorang. Ketiga adalah usaha penutur untuk bersikap serelevan mungkin. Dengan demikian, pendengar atau kawan tutur beranggapan bahwa apa yang dituturkan penutur adalah relevan (Cummings, 2007: 25-26).

Prinsip relevansi menjadi landasan komunikasi yang disebut Sperber dan Wilson (dalam Gunarman, 2004: 90-91) sebagai komunikasi ostensif. Komunikasi ostensif merupakan komunikasi 
yang mengandung jaminan adanya relevansi optimal. Artinya, sebuah komunikasi yang relevan adalah komunikasi yang menghasilkan efek kontekstual atau interaksi antara informasi lama yang sudah ada dalam benak dan informasi baru. Jika informasi baru berhubungan dengan informasi lama, maka akan muncul inferensi (simpulan) baru yang diambil dan diproses oleh mitra tutur. Semakin sedikit upaya yang diperlukan untuk memproses informasi baru, semakin besar pula relevansinya.

Efek kontekstual menurut Sperber dan Wilson (dalam Nurjanah, 2016) ini bisa dikenali dengan stimulus ostensif yang dimanfaatkan dalam tuturan, stimulus ini bisa berupa informasi yang sudah diketahui oleh mitra tutur sebelumnya. Dalam konteks iklan, stimulus ostenstif bisa dalam bentuk visual.

Cruse (dalam Gunarman, 2004: 91) kemudian menguraikan bahwa nilai relevansi atau derajat relevansi dapat diukur berdasarkan efek kontekstual dan usaha dalam memproses. Komunikasi yang memiliki derajat relevansi yang tinggi atau paling relevan adalah komunikasi yang mengandung banyak efek kontekstual sehingga membutuhkan upaya yang sedikit untuk memprosesnya. Sementara itu, komunikasi yang memiliki derajat relevansi yang kecil atau tidak relevan manakala mengandung sedikit efek kontekstual dan membutuhkan upaya yang besar dalam memprosesnya.

Dari uraian tersebut dapat disimpulkan bahwa dalam teori relevansi, penutur berupaya menghasilkan tuturan yang relevan dengan memuat efek kontekstual yang memadai sehingga tuturan tersebut tidak membutuhkan upaya yang besar. Hal tersebut berlaku dalam bahasa yang digunakan dalam iklan. Tuturan iklan pada umumnya mengandung informasi yang sudah diketahui oleh kawan tuturnya sembari memuat informasi baru mengenai keunggulan produk tersebut dibandingkan produk lain sehingga menghasilkan inferensi atau menambah skemata mitra tutur dalam hal ini adalah pangsa pasarnya. 


\section{Iklan dalam Kajian Pragmatik}

Iklan (advertising) secara harfiah memiliki arti memperoleh perhatian atau to turn attention. Definisi ini merujuk bahwa iklan disiarkan dengan tujuan untuk mendapatkan perhatian secara terus menerus. Hal ini dilakukan untuk menstimulus keinginan atau mengarahkan tindakan seseorang untuk membeli barang atau jasa (Berger, 2013: 12). Senada dengan yang dipaparkan Tanaka yang merangkum berbagai pandangan ahli. Dalam karyanya, Tanaka menyatakan bahwa iklan memiliki dua fungsi yaitu, menginformasikan dan membujuk. Kedua fungsi itu tidak berada pada posisi yang sama, melainkan berada pada posisi superordinat dan subordinat. Fungsi informasi berada pada posisi superordinat. Agensi iklan tidak hanya menginformasikan sesuatu kepada khalayak umum tentang dunia, melainkan untuk menjual produknya. Agensi iklan yang berhasil adalah agensi yang mampu memberikan informasi sekaligus mampu membujuk pangsa pasarnya untuk membeli produknya. Sebaliknya, agensi yang gagal adalah agensi yang mampu memberikan informasi mengenai produknya, tetapi tidak berhasil membujuk pasarnya sehingga produknya tidak terjual (dalam Nurjanah, 2016).

Untuk mendukung kedua fungsi yang dipaparkan Tanaka, iklan sebisa mungkin memiliki daya pikat secara visual dan verbal. Secara visual, iklan pada umumnya memanfaatkan model, tata warna, peletakan huruf, jenis huruf, ukuran huruf untuk menarik perhatian pangsa pasarnya. Secara verbal, iklan akan memanfaatkan bahasa atau tuturan yang menarik dan mudah dipahami oleh pangsa pasarnya.

Dengan demikian, iklan dapat dikatakan sebagai bentuk komunikasi. Tanaka (dalam Nurjanah, 2016) mengatakan bahwa komunikasi dalam iklan melibatkan peserta komunikasi atau kawan tutur (pangsa pasar). Kawan tutur bisa diidentifikasikan dari stratifikasi sosial (atas, menengah, dan bawah), jenis kelamin, segmentasi usia, dan lain-lain. Untuk mengidentifikasi siapa kawan tutur yang diincar oleh agensi, umumnya iklan akan menampilkan melalui bentuk visual dan tuturannya. 
Penelitian mengenai iklan dengan memanfaatkan teori relevansi sudah dilakukan. Salah satunya penelitian yang ditulis oleh Nurjanah (2016), "Membedah Relevansi dalam Iklan WRP" yang membahas relevansi dalam iklan WRP 6 day diet pack dan menemukan makna yang terkandung dalam iklan tersebut adalah produk tersebut menawarkan cara gagasan tentang diet dalam arti membentuk tubuh ideal tanpa mengandung risiko yang berbahaya. Penelitian lain adalah Nurjanah dan Pratiwi, "Citra Perempuan Berhijab dalam Iklan Sampo: Sebuah Kajian Pragmatik”. Penelitian tersebut juga menggunakan teori relevansi. Hasil yang ditemukan melalui iklan tersebut menampilkan citra muslimah yang meskipun berhijab ia bisa merawat tubuhnya, terkhusus rambut (walau tertutup hijab) dan bisa beraktivitas dengan bebas; kedua, perempuan yang berjilbab yang ditampilkan dalam iklan adalah perempuan muda yang aktif, energik, dan relijius (Nurjanah \& Pratiwi, 2019).

\section{METODE PENELITIAN}

Metode yang digunakan dalam penelitian ini adalah metode penelitian deskripsi kualitatif. Metodologi kualitatif menghasilkan data deskriptif berupa kata-kata tertulis atau lisan dari orang-orang dan perilaku yang dapat diamati (Muhammad, 2014: 30). Muhammad (dalam Muhammad, 2014: 31) mengemukakan bahwa salah satu fenomena yang dapat menjadi objek penelitian kualitatif adalah peristiwa komunikasi atau berbahasa karena peristiwa ini melibatkan tuturan, makna semantik tuturan, penutur, maksud yang bertutur, situasi tuturan, peristiwa tuturan, tindak tutur, dan latar tuturan.

Sumber data yang dimanfaatkan dalam penelitian ini adalah iklan Johnson's CottonTouch 2in1 hair and body baby bath. Iklan ini sempat tayang di televisi, lalu diunggah di situs YouTube pada 06 Juli 2019 dengan memakai tagar \#ChooseGentle \#ChooseGentle_ID.

Data dalam penelitian ini adalah tuturan iklan Johnson's CottonTouch 2in1 hair and body baby bath. Data diambil dengan mengunduh video iklan dari tautan https:/www.youtube.com/ 
watch?v=LQVzHtxeH3U. Setelah diunduh, tuturan dalam iklan ditranskripsi.

Berikut adalah tuturan dalam iklan tersebut.

1. Kulit halus bayi selalu butuh yang terlembut.

2. Baru! Johnson's CottonTouch 2 in1 hair and body baby bath.

3. Terbuat dari kapas alami.

4. Ultralight dan Hypoallergenic.

5. Di pojok sebelah kanan iklan terdapat lambang MUI dan tulisan 'tersertifikasi halal'.

6. Untuk sentuhan selembut kapas.

7. Wangi lembut yang ngegemesin, jadi pengen peluk dan cium si kecil terus.

8. Johnson's cottontouch baru.

9. Choose gentle.

10. Kulit bayi $30 \%$ lebih tipis dari kulit dewasa, makanya si kecil butuh yang terlembut untuk menjaga kulitnya tetap bersih dan sehat.

11. Untuk sentuhan selembut kapas, Johnson's CottonTouch 2in 1 hair and body baby bath adalah pilihan yang tepat!

12. Terbuat dari kapas alami yang membuat formulanya sangat lembut, hypoallergenic, dan telah teruji oleh dermatologist.

13. Yuk Bunda saatnya mandikan si kecil dengan produk Johnson's CottonTouch 2in1 hair and body baby bath dengan membeli produknya di bit.ly/CottonTouchYT.

Selain menjadikan tuturan iklan sebagai data, peneliti juga memperhatikan gerak visual yang terdapat dalam iklan yang dapat dimanfaatkan dalam melakukan analisis tuturan dengan memanfaatkan teori relevansi.

Teknik analisis data menggunakan model interaktif. Miles Huberman (2014: 14) membagi model interaktif menjadi tiga bagian, yaitu reduksi data, sajian data, dan penarikan kesimpulan. Data yang terkumpul selanjutnya akan direduksi atau dikurangi, kemudian 
disajikan sesuai dengan teori yang digunakan, yaitu relevansi milik Sperber dan Wilson dan iklan menurut Tanaka. Langkah terakhir, yaitu penarikan kesimpulan dari data-data yang telah dianggap valid dengan teori.

Analisis dilakukan dengan beberapa langkah. Pertama, tuturan dianalisis untuk melihat siapa kawan tutur atau pangsa pasar dari iklan tersebut. Kedua, tuturan dianalisis untuk memperoleh efek kontekstual dan stimulus ostensif. Ketiga, analisis dilakukan untuk memperoleh makna tuturan yang terkandung dalam iklan tersebut.

\section{HASIL PENELITIAN DAN PEMBAHASAN}

Pada bagian ini peneliti melakukan beberapa tahap analisis dalam iklan produk bayi Johnson's CottonTouch 2in1 hair and body baby bath. Pertama, peneliti menganalisis siapa kawan tutur iklan Johnson's CottonTouch 2in1 hair \& body baby bath. Kedua, analisis mengenai efek kontekstual dan stimulus ostentif, apa yang ingin diberikan dan diketahui kawan tutur melalui iklan tersebut. Ketiga, analisis mengenai asumsi yang ingin diberikan dari penutur kepada kawan tutur.

Iklan Johnson's tersebut dimulai dari seorang bayi yang tertawa ketika dimandikan oleh seorang ibu dengan kisaran usia 2530-an. Sabun yang dipakai ibu untuk memandikan bayinya adalah produk Johnson's CottonTouch 2in1 hair \& body baby bath. Sentuhansentuhan yang diberikan oleh ibu, membuat si bayi nyaman dan terus tersenyum. Lalu, muncul anak laki-laki di samping sang ibu. Ia mengamati adiknya sedang dimandikan.

Dilihat dari visual iklan, penutur cukup jelas dalam mengungkapkan kawan tuturnya yaitu, seorang wanita yang ingin atau sudah memiliki bayi. Hal ini dapat diidentifikasi melalui model wanita yang menjadi ibu yang sedang memandikan bayi. Terlihat pula model wanita itu masih muda yaitu, kisaran usia 25-30-an, karena ia sudah memilki dua anak. Identifikasi mengenai derajat sosial atau stratafikasi sosialnya adalah kelas menengah ke atas. Karena jika dilihat dari latar tempat atau rumah si ibu yang cukup 
bagus karena ada sofa, luas, dan terang. Artinya, kawan tutur yang diincar oleh iklan ini adalah seorang wanita yang ingin atau sudah memiliki bayi (seorang ibu) dengan kisaran usia 25-30-an dari kalangan kelas menengah ke atas.

Tentunya agensi sudah memperkirakan tuturan yang akan disampaikan kepada kawan tutur melalui iklan. Oleh karena itu, iklan hadir memperkenalkan produknya dengan memanfaatkan efek kontekstual dan stimulus ostensif iklan untuk memikat kawan tutur (pangsa pasarnya). Melalui efek kontekstual, agensi menanamkan praanggapan yang relevan dan pasti diterima oleh pangsa pasarnya (stimulus ostentif).

Anggapan yang pertama adalah bahwa seorang ibu harus memberikan yang terbaik untuk anaknya, terkhusus ketika anaknya baru lahir (bayi). Anggapan ini membuat sang ibu akan lebih berhatihati dalam memilih kebutuhan bayinya. Apalagi jika itu menyangkut kulit bayi, karena seperti yang diketahui, kulit bayi memang sangat sensitif daripada orang dewasa.

Anggapan yang kedua adalah produk Johnson's CottonTouch 2in1 hair \& body baby bath memiliki kandungan untuk merawat kulit bayi yang halus dan sensitif, seperti yang telah dituturkan penutur dalam iklan dan deskripsi di akun Youtube Johnson's Baby Indonesia bahwa produk tersebut Terbuat dari kapas alami yang membuat formulanya sangat lembut, hypoallergenic, dan telah teruji oleh dermatologis. Artinya, produk yang diiklankan ini aman untuk diggunakan ibu kepada bayinya.

Stimulus pertama yang diberikan oleh iklan Johnson's yang diwakili oleh penutur perempuan bersuara halus dan menenangkan. Suara penutur perempuan itu membuat para ibu membenarkan apa yang dituturkan oleh olehnya. Stimulus kedua adalah dengan menampilkan bayi yang tersenyum dan tertawa karena sentuhan yang diberikan ibunya saat mandi. Stimulus ketiga adalah adegan ibu dan seorang anak laki-laki yang tidak tahan untuk mencium si bayi setelah mandi. Stimulus-stimulus itulah yang merangsang kawan tutur atau pangsa pasar untuk membeli produk yang diiklankan oleh 
Johnson's. Stimulus keempat adalah bahwa produk yang diiklankan ini memiliki dua kegunaan dalam satu kemasan yaitu, sebagai sampo dan sabun mandi. Stimulus kelima adalah dengan adanya logo MUI dan tulisan 'tersertifikasi halal'.

Jika dilihat dari data yang telah dipaparkan sebelumnya, penutur ingin memikat kawan tutur. Makna tuturan yang disampaikan oleh penutur melalui iklan tersebut memanfaatkan asumsi yaitu, pertama, kulit bayi halus dan sensitif. Kedua, menjadi ibu yang cerdas. Kemudian, asumsi yang terdapat dalam iklan Johnson's adalah sebagai berikut.

a. Asumsi bahwa produk yang diiklankan terbuat dari kapas alami sehingga akan terasa lembut di kulit bayi.

b. Asumsi bahwa produk sangat praktis, karena memiliki dua kegunaan dalam satu kemasan. Hal itu membuat para ibu (pangsa pasar) akan merasa lebih hemat dengan membeli dan memakai produk tersebut.

c. Asumsi bahwa ibu sebagai pangsa pasar harus memberikan yang terbaik kepada si kecil dengan memakai produk Johnson's CottonTouch 2in1 hair \& body baby bath karena produk yang diiklankan terbuat dari bahan yang aman dan halus untuk kulit bayi yang lembut.

d. Asumsi bahwa produk tersebut juga harum sehingga membuat siapapun ingin mencium dan memeluk si bayi.

e. Asumsi bahwa produk yang dijual sudah disertifikasi halal oleh MUI sehingga prosuk ini pun aman untuk si kecil.

Dengan memanfaatkan asumsi-asumsi di atas, maka penutur ingin mengatakan kalau seharusnya dalam memilih produk bayi, pastikan produk-produk itu terbuat dari bahan apa saja, apakah aman, atau malah membahayakan. Kemudian, zaman sudah serba praktis. Terbukti dengan adanya produk bayi Johnson's 2 in 1 . Tidak perlu lagi membeli dua jenis produk yang berbeda jika ada satu produk yang sudah mencakup dua jenis sekaligus. Maksudnya, para ibu tidak perlu lagi membeli sabun mandi dan sampo secara terpisah, karena Johnson's sudah memberikan atau menawarkan 
produk dengan dua kegunaan tersebut dalam satu kemasan. Para ibu bisa berhemat dengan membeli produk Johnson's tersebut. Selain itu, produk yang diiklankan tersebut menawarkan keharuman dari produk yang membuat orang-orang akan terpikat dengan sang bayi karena keharuman tubuhnya.

Berdasarkan analisis tersebut, dapat disimpulkan bahwa derajat relevansi yang miliki oleh iklan tersebut bersifat tinggi karena iklan ini memanfaatkan bahasa yang mudah dipahami. Selain itu, iklan ini juga memanfaatkan praanggapan, asumsi, dan informasi yang selama ini ada dalam benak kawan tuturnya sehingga tidak membutuhkan waktu yang lama untuk memproses iklan tersebut.

\section{Makna Tuturan dalam Iklan}

Makna penutur dalam iklan Johnson's CottonTouch 2in1 hair \& body baby bath disampaikan dengan memanfaatkan tindak tutur langsung sehingga kawan tutur memahami pesan yang ingin disampaikan penutur. Iklan ini berusaha untuk menyampaikan bahwa produk tersebut merupakan produk yang mempertimbangkan kelembutan, kesehatan, dan halal.

Makna iklan Johnson's CottonTouch 2in1 hair \& body baby bath sebagai produk yang lembut untuk bayi. Hal ini dibuktikan dengan kata yang muncul dalam iklan tersebut, seperti kata terlembut dan lembut. Terutama pada tuturan "Kulit halus bayi selalu butuh yang terlembut." dan tuturan "Kulit bayi 30\% lebih tipis dari kulit dewasa, makanya si kecil butuh yang terlembut untuk menjaga kulitnya tetap bersih dan sehat". Dari dua tuturan tersebut, terlihat bahwa iklan tersebut menegaskan bahwa dalam perawatan bayi, kawan tutur membutuhkan produk yang lembut.

Adapun pencitraan yang dimunculkan dalam produk ini adalah kapas. Kapas merupakan tanaman yang buahnya dimanfaatkan untuk tekstil dan perawatan kecantikan. Dalam produk ini pun, kapas menjadi salah satu komposisi yang ditonjolkan. Citra rabaan yang muncul dari kata kapas adalah lembut. Dengan memanfaatkan kata kapas, penutur mencoba menghadirkan sentuhan produk ini seperti sentuhan lembut pada kapas. Citraan kata kapas pada produk 
ini menggiring pemahaman pada kawan tutur bahwa produk ini tidak membahayakan atau menyakiti kulit bati bayi karena sifat dari produk ini lembut dan membuat kulit bayi terjaga.

Makna lain yang muncul dalam tuturan iklan tersebut adalah produk Johnson's CottonTouch 2in1 hair \& body baby bath adalah produk yang sesuai dengan standar kesehatan. Ada dua kata yang menjadi acuan dalam penonjolan aspek kesehatan, yaitu dermatologist Hypoallergenic. Dua kata tersebut terdapat dalam tuturan "Terbuat dari kapas alami yang membuat formulanya sangat lembut, hypoallergenic, dan telah teruji oleh dermatologist."

Secara literal menurut Oxford Dictionary, hypoallergenic adalah materi yang tidak akan menyebabkan alergi pada penggunanya. Istilah tersebut sering ditemukan dalam kosmetik atau produk perawatan kulit. Istilah ini menandakan bahwa produk tersebut diformulasikan untuk sebisa mungkin tidak menimbulkan reaksi alergi. Adanya label hypoallergenic akan sangat membantu orang-orang yang memiliki masalah kulit sensitif atau mudah iritasi. Kulit bayi rentan terkena iritasi. Dengan demikian, dengan adanya label tersebut membuat para ibu akan tertarik dengana produk yang ditawarkan. Tetapi, hypoallergenic bukan berarti tidak benarbenar tidak menimbulkan alergi. Akan lebih baik, produk yang akan digunakan tetap dites terlebih dahulu dengan mencobanya di punggung tangan untuk mengetahui reaksinya terhadap kulit.

Selain itu, makna lain yang terkandung dalam iklan ini adalah produk Johnson's CottonTouch 2in1 Hair \& Body Baby Bath adalah produk yang halal. Hal ini dibuktikan dengan tuturan 5. Di pojok sebelah kanan iklan terdapat lambang MUI dan tulisan 'tersertifikasi halal'. Hal ini menunjukkan bahwa produk ini tidak mengandung komposisi yang haram. Dalam hal ini, terlihat bahwa dalam iklan ini, aspek halal menjadi penting. Tentu ini menunjukkan bahwa iklan ini ingin menyampaikan bahwa produk ini aman untuk orang muslim.

Dengan demikian, tidak menutup kemungkinan jika pangsa pasar yang sebenarnya adalah pangsa pasar muslim. Mengingat mayoritas penduduk Indonesia muslim. Adanya sertifikasi halal 
membuat produk bayi tersebut diminati oleh konsumen muslim. Strategi tersebut harus dilakukan supaya produk yang mereka buat dapat digunakan oleh beragam lapisan masyarakat.

\section{PENUTUP}

Berdasarkan pada penjelasan di atas, berikut beberapa yang dapat disimpulkan. Pertama, iklan Johnson's CottonTouch 2in1 Hair \& Body Baby Bath memiliki derajat relevansi yang tinggi karena memanfaatkan efek kontekstual yang banyak dan tidak membutuhkan proses yang lama dalam memproses iklan tersebut. Kedua, makna penutur disampaikan oleh agensi iklan adalah produk ini merupakan produk yang lembut, sesuai dengan standar kesehatan dan halal sehingga produk bayi tersebut dapat digunakan oleh beragam lapisan masyarakat.

\section{DAFTAR PUSTAKA}

Berger. (2013) Dictionary of Advertising and Marketing Concepts. Left Coast Press: Walnut Creek.

Cummings, L. (2007). Pragmatik: Sebuah Penelitian Multidisipliner. Yogyakarta: Pustaka Pelajar.

Gunarman, A. (2004). "PELBBA 17 Pertemuan Linguistik Pusat Kajian Bahasa dan Budaya Atma Jaya Ketujuh Belas". Jakarta: Atmajaya.

Muhammad. (2014). Metode Penelitian Bahasa. Jogjakarta: Ar-Ruzz Media.

Miles, M. B., Huberman, A. M. (2014). Qualitative Data Analysis, A Methods Sourcebook, Edition 3. USA: Sage Publications. Terjemahan Tjetjep Rohindi Rohidi, UI-Press.

Nurjanah N., Pratiwi R. (2019). Citra Perempuan Berhijab dalam Iklan Sampo: Sebuah Kajian Pragmatik. Jurnal Pena Indonesia, 69-78 Vol. 5 No. 1. 
Nurjanah, N. (2016). Membedah Relevansi dalam Iklan "WRP". Jurnal Dialektika, 67-86 Vol. 3 No. 1.

Rahardi, Kunjana, dkk. (2019). Pragmatik: Fenomena Ketidaksantunan Berbahasa. Jakarta: Penerbit Erlangga.

Sperber, D., Wilson, D. (1995). Relevance: Communication and Cognition. Oxford: Blackwell. 